\title{
Revisiting the Libya/Malta Decision and Assessing its Relevance (or otherwise) to the East China Sea Dispute
}

\author{
Fayokemi Olorundami*
}

\begin{abstract}
In the Libya/Malta case, the ICJ held that where the area to be delimited between two opposite States measures less than 400 nautical miles, distance, not natural prolongation determines title to the continental shelf. This was the Court's interpretation of the definition of the continental shelf in Article 76(1) of the Law of the Sea Convention and of the relationship between the continental shelf and the exclusive economic zone. In the East China Sea which measures less than 400 nautical miles, China relies on natural prolongation while Japan relies on the distance principle. This paper analyses the Libya/Malta decision to ascertain its correctness or otherwise, and its usefulness for resolving the East China Sea dispute. The central argument in this paper is that the decision is inapplicable to the East China Sea dispute because it is incompatible with Articles 76(1), 77(3) and 56(3) of the Law of the Sea Convention.
\end{abstract}

\section{Introduction}

1. The Case Concerning the Continental Shelf (Libyan Arab Jamabiriya/Malta) ${ }^{1}$ was decided by the International Court of Justice (ICJ) in 1985. However, its effect has reverberated down the years to this present day. In that case, the Court laid down the rule that where the area to be delimited between two States measures less than 400 nautical miles, geological and geomorphological factors relating to the seabed play no role for determining title to the continental shelf. This was the Court's interpretation of the definition of the continental shelf as provided for in Article 76(1) of the United Nations Convention on the Law of the Sea (UNCLOS). ${ }^{2}$ (That definition provides two

* The author is a Barrister and Solicitor of the Supreme Court of Nigeria, a $\mathrm{PhD}$ Candidate in international law at the University of Aberdeen, UK and a Lecturer at the University of Greenwich, UK. Author can be reached at f.owolabi@abdn.ac.uk

1 ICJ Reports 1985, 13.

21833 UNTS 3. 
alternative bases for continental shelf entitlement, namely natural prolongation up to the outer edge of the continental margin and 200 nautical miles distance where the continental margin does not extend up to that distance.) This was also the Court's interpretation of the relationship between the continental shelf and the exclusive economic zone (EEZ) under the UNCLOS considering that Article 57 permits all States to establish an EEZ not exceeding 200 nautical miles from the coasts.

2. In the East China Sea, China and Japan have been unable to delimit their maritime boundaries. This dispute is rooted in the different interpretations each State holds regarding entitlement to the continental shelf. While China relies on the doctrine of natural prolongation all the way to the outer edge of the continental margin, Japan relies on the distance principle. Reliance on these different entitlement bases yields different results in the East China Sea. Moreover, the area to be delimited between China and Japan measures less than 400 nautical miles from both coasts. In view of this, Japan has asserted that it is not possible to establish the outer limits of the continental shelf extending beyond 200 nautical miles where the area to be delimited is less than 400 nautical miles, and relies on the Libya/Malta decision as international law governing this dispute.

3. This paper analyses the Libya/Malta decision to ascertain its correctness or otherwise and whether or not it is useful for resolving the East China Sea dispute. It begins with a synopsis of the decision, then provides specific details of the East China Sea dispute before moving on to critically assess the decision and its applicability or otherwise to the dispute. The central argument in this paper is that the decision is inapplicable to the East China Sea dispute because it is incompatible with Articles 76(1), 77(3) and 56(3) of the UNCLOS.

\section{The Libya/Malta Decision}

4. By a Special Agreement signed on 23 May 1976, Libya and Malta requested the ICJ to state the principles and rules of international law applicable to both parties in the delimitation of their continental shelves. ${ }^{3}$ As Libya was not a party to the 1958 Convention on the Continental Shelf, 4 it was agreed by both parties that customary international law governed the resolution of the dispute. Both parties had signed the 1982 UNCLOS and although this

3 Libya/Malta case, above n.1, 16.

4499 UNTS 311. 
Convention did not come into force until 1994, they nevertheless agreed that some of its provisions which reflected customary international law could be applied to resolve the dispute. What constituted customary international law in the circumstances though was a point of difference for the parties. ${ }^{5}$ Libya contended that the natural prolongation of the land territory of States constituted the basis for entitlement to the continental shelf. Consequently, when there was a fundamental discontinuity in the seabed that indicated the end of one continental shelf and the beginning of another, a criterion for delimitation could be derived therefrom. Libya further argued that equitable principles dictated that delimitation must be carried out in a manner that leaves to each party all those areas that constitute a natural prolongation of its land territory, without encroachment on the natural prolongation of the other State. ${ }^{6}$

5. Malta, on the other hand, argued that natural "prolongation is no longer defined by reference to physical features, geological or bathymetric, but by reference to a certain distance from the coasts." 7 Reliance for this position was founded on the inclusion in the then draft UNCLOS of a 200 nautical mile distance continental shelf as part of the definition of the continental shelf and a 200 nautical mile EEZ. In view of this, Malta stated that the drawing of a median line, every point of which is equidistant from the nearest point on the baselines, would produce an equitable solution.

6. In resolving this dispute, the Court decided that the regime of the continental shelf and the EEZ were linked together in modern law and insofar as rights over the seabed of the continental shelf are the same as rights over the seabed of the EEZ, then the legally permitted extent of the EEZ was a relevant factor in the delimitation of the continental shelf. ${ }^{8}$ And further, that

since the development of the law enables a State to claim that the continental shelf appertaining to it extends up to as far as 200 miles from its coast, whatever the geological characteristics of the corresponding sea-bed and subsoil, there is no reason to ascribe any role to geological or geophysical factors within that distance either in verifying the legal title of the States concerned or in proceeding to a delimitation as between their claims. This is especially clear where

$5 \quad$ Libya/Malta case, above n.1, 16 para 26.

6 ibid., 18.

7 ibid., 31, para 30.

8 ibid., 33, para 33. 
verification of the validity of title is concerned, since, at least in so far as those areas are situated at a distance of under 200 miles from the coasts in question, title depends solely on the distance from the coasts of the claimant States of any areas of sea-bed claimed by way of continental shelf, and the geological or geomorphological characteristics of those areas are completely immaterial. It follows that, since the distance between the coasts of the Parties is less than 400 miles, so that no geophysical feature can lie more than 200 miles from each coast, the feature referred to as the "rift zone" cannot constitute a fundamental discontinuity terminating the southward extension of the Maltese shelf and the northward. ${ }^{9}$

This dictum and associated ones are analysed subsequently.

\section{East China Sea Dispute}

\section{III.A. China's Position}

7. China ratified the UNCLOS on 7 June 1996. In ratifying the Convention, it declared that in accordance with the former, "the People's Republic of China shall enjoy sovereign rights and jurisdiction over an exclusive economic zone of 200 nautical miles and the continental shelf."10 In 1997, the Chinese Ministry of Foreign Affairs partly stated China's position regarding its entitlement to the continental shelf of the East China Sea thus: "[t]he East China Sea continental shelf is the natural extension of the Chinese continental territory. The People's Republic of China has inviolable sovereignty over the East China Sea continental shelf." "11 Further, in 1998, China promulgated its Exclusive Economic Zone and Continental Shelf Act providing in Article 2 that:

The exclusive economic zone of the People's Republic of China is an area beyond and adjacent to the territorial sea of the People's Republic

\footnotetext{
9 ibid., 35, para 39.

10 'Declarations or Statements upon UNCLOS Ratification' $<$ www.un.org/depts/los/convention_agreements/convention_declarations. htm\#China Upon ratification> accessed 17 February 2015.

11 Statement by the Chinese Ministry of Foreign Affairs, June 13, 1977, Beijing Review (17 June 1997) 17.
} 
of China extending to a distance of 200 nautical miles from the baselines from which the breadth of the territorial sea is measured [while] [t]he continental shelf of the People's Republic of China comprises the seabed and subsoil of the submarine areas that extend beyond its territorial sea throughout the natural prolongation of its land territory to the outer edge of the continental margin, or to a distance of 200 nautical miles from the baselines from which the breadth of the territorial sea is measured where the outer edge of the continental margin does not extend up to that distance. ${ }^{12}$

8. Article 2 further provides that where there are conflicting claims between China and other States with opposite or adjacent coasts regarding the EEZ and the continental shelf, the matter shall be settled by agreement delimiting these zones on the basis of international law and in accordance with the principle of equity. China's domestic law mirrors Article 76(1) of the UNCLOS regarding entitlement to the continental shelf insofar as it sets out the twin criteria for entitlement to the continental shelf, namely the natural prolongation of the land territory to the outer edge of the continental margin and 200 nautical miles measured from the baselines where the outer edge of the continental margin does not extend up to that distance. In consonance with its domestic law and the UNCLOS, China claims that in the East China Sea, it is entitled to a continental shelf extending from its coast throughout the natural prolongation of the land territory to the outer edge of the continental margin, which outer edge reaches up to the Okinawa Trough. ${ }^{13}$ Consequently, the Okinawa Trough is regarded as the natural boundary between its continental shelf and Japan's as it disrupts the unity of the East China Sea continental shelf. ${ }^{14}$ As the distance between China's coast and the Okinawa

12 (Adopted at the third session of the Standing Committee of the Ninth National People's Congress, 26 June 1998) $<$ www.un.org/depts/los/LEGISLATIONANDTREATIES/PDFFILES/ch n_1998_eez_act.pdf > accessed 2 July 2015.

13 'China's Oil and Gas Development in the East China Sea Is Justified and Legitimate' (Ministry of Foreign Affairs of the People's Republic of China, 27 July 2015)<www.fmprc.gov.cn/mfa_eng/wjbxw/t1284278.shtml> accessed 18 December 2015.

14 Suk-Kyoon Kim, Perspectives on East China Sea Maritime Disputes: Issues and Context: in Moon-Sang Kwon, Clive H. Schofield, and Seokwoo Lee (eds.), The Limits of Maritime Delimitation (Martinus Nijhoff Publishers 2013), 290. The status of the Okinawa Trough as fundamental discontinuity 
Trough is more than 200 nautical miles, China sought to comply with the provisions of Article 76 regarding the establishment of the outer limit of the continental shelf.

9. On 11 May 2009, China submitted preliminary information indicative of the outer limits of the continental shelf to the Commission on the Limits of the Continental Shelf (CLCS). Subsequently, on 14 December 2012, China submitted to the CLCS information on the limits of its continental shelf beyond 200 nautical miles from the baselines from which the breadth of its territorial sea is measured in part of the East China Sea. ${ }^{15}$ In its submission, China advanced its argument that

The geomorphologic and geological features show that the continental shelf in the East China Sea (hereinafter referred to as "ECS") is the

in the continental shelf of the East China Sea is a point of contention between the parties. However, some opinions regard it as such. This is different from the question of whether or not it should be relevant to the delimitation. See GAO Jianjun, The Okinawa Trough Issue in the Continental Shelf Delimitation Disputes within the East China Sea, 9 Chinese JIL 143-177 (2010). For examples of opinions regarding the Okinawa Trough as a discontinuity in the continental shelf, see Prescott and Schofield who write that "[g]eologically and geomorphologically the continental margin bounded by the Okinawa Trough is Chinese. It stretches seawards from the mainland coast of China.... The imperfect concept of natural prolongation fashioned in the North Sea by the International Court of Justice in 1969 is perfectly illustrated by the continental margin of the East China Sea." Victor Prescott and Clive Schofield, The Maritime Political Boundaries of the World (2nd ed. 2005) 439. See also Allen and Mitchell who note that the seabed of the East China Sea consists of three distinct features: a broad continental shelf area which stretches from China's coast, the Okinawa Trough and the Ryukyu Ridge. Donald R. Allen and Patrick H. Mitchell, The Legal Status of the Continental Shelf of the East China Sea, 51 Oregon Law Review (1972) 789, 791. Without debating this point, this paper considers the application of the Libya/Malta decision to the East China Sea dispute on the assumption that the Okinawa Trough represents a break in the East China Sea continental shelf.

15 Division of Ocean Affairs and the Law of the Sea, 'Commission on the Limits of the Continental Shelf (CLCS) Outer Limits of the Continental Shelf beyond 200 Nautical Miles from the Baselines: Submissions to the Commission: Submission by the People's Republic of China' $<$ www.un.org/depts/los/clcs_new/submissions_files/submission_chn_63_ 2012.htm> accessed 17 January 2015. 
natural prolongation of China's land territory, and the Okinawa Trough is an important geomorphologic unit with prominent cut-off characteristics which is the termination to where the continental shelf of the ECS extends. The continental shelf in ECS extends beyond 200 nautical miles from the baselines from which the breath of the territorial sea of China is measured. ${ }^{16}$

China asserts that its entitlement to the continental shelf up to the outer edge of the continental margin is based on Article 76 of the UNCLOS and relies on the Convention which provides that where a State claims a continental shelf beyond 200 nautical miles from the baselines from which the breath of the territorial sea is measured, the outer continental shelf shall be delineated in accordance with Article 76(4-6) and such coastal State shall submit to the CLCS information on the limits of the continental shelf beyond 200 nautical miles. ${ }^{17}$ In defence of its submission, China invokes paragraph (ii) of Article 76(4) by drawing 'a line delineated in accordance with paragraph 7 by reference to fixed points not more than 60 nautical miles from the foot of the continental slope. ${ }^{18}$ The fixed points comprising the line of the outer limits of the continental shelf on the seabed, drawn in accordance with the preceding paragraph 4(ii) does not exceed 350 nautical miles from the baselines from which the breadth of the territorial sea is measured.

10. In light of the above, China advocates for the delimitation of the continental shelf of the East China Sea based on equitable principles taking into foremost consideration, the natural prolongation principle, which in this case is exemplified in the Okinawa Trough being the natural break of two different continental shelves in the East China Sea. China's position on entitlement thus weighs heavily on its preferred method of delimitation. Bearing in mind that the Okinawa Trough is located at a distance more than 200 nautical miles from China's coast but well within 200 nautical miles of Japan's, ${ }^{19}$ if the boundary line between China and Japan is drawn along the

16 'Submission by the People's Republic of China Concerning the Outer Limits of the Continental Shelf beyond 200 Nautical Miles in Part of the East China

Sea: Executive Summary' 1

$<$ www.un.org/depts/los/clcs_new/submissions_files/chn63_12/executive \%20summary_EN.pdf $>$ accessed 17 February 2016.

17 ibid., 2-3.

18 ibid., 3.

19 GAO, above n. 14, 145. 
Okinawa Trough as claimed by China, China would have sovereign rights to about two-thirds of the East China Sea Continental Shelf. ${ }^{20}$ China's claims meet with opposition from Japan which also relies on the UNCLOS and international law to advance its position on entitlement to the continental shelf and consequently, its delimitation.

\section{III.B. Japan's Position}

11. Japan promulgated its 1996 Law on the Exclusive Economic Zone and the Continental Shelf ${ }^{21}$ in which it set out its entitlement and rights to the EEZ and the continental shelf. In Article (1)2 of the Law, Japan states that its EEZ 'comprises the areas of the sea extending from the baseline of Japan ... to the line every point of which is 200 nautical miles from the nearest point on the baseline of Japan (excluding therefrom the territorial sea) and its subjacent seabed and its subsoil.' Article 1(2) goes on to state that where any part of the 200 nautical mile line lies beyond the median line between Japan and a neighbouring State, Japan's EEZ terminates at that median line or any other line agreed upon between Japan and the second mentioned State as a substitute for the median line.

12. Similarly for its continental shelf, the Japanese Law provides that the continental shelf extends from the baseline of Japan to the line every point of which is 200 nautical miles from the nearest point on the baseline of Japan; and where any part of the 200 nautical mile line lies beyond the median line measured from Japan's baselines, then the median line or any other line agreed upon between Japan and a second State shall be the dividing line between the continental shelf spaces appertaining to both States. ${ }^{22}$ Therefore the outer limit of Japan's continental shelf is the median line or another line agreed in substitution thereof.

13. In response to China's position on the Okinawa Trough, Japan argues vehemently against regarding the Trough as the natural termination of the East China Sea continental shelf, holding that the Okinawa Trough is a mere casual indent in the natural prolongation of the continental shelf of both

20 Suk Kyoon Kim, Understanding Maritime Disputes in Northeast Asia: Issues and Nature, 23 International Journal of Marine and Coastal Law (2008) 213, 223.

21 Law No. 74 of 1996 <http://faolex.fao.org/docs/pdf/jap13392.pdf> accessed 6 October 2015.

22 Art 2. 
States and therefore does not have the effect of disrupting the unity of the continental shelf. ${ }^{23}$ Relying on the Libya/Malta decision, Japan further insists that the natural prolongation principle is inapplicable where the distance between the lengths of the coasts of the disputing States is less than 400 nautical miles. As recently as August 2015, Japan declared that "China's claim for the entitlement of continental shelf up to the Okinawa Trough is therefore baseless in light of international law today." ${ }_{24}$

14. In response to China's submission of preliminary information to the CLCS regarding the limits of its outer continental shelf extending beyond 200 nautical miles from its coasts, Japan protested thus:

It is indisputable that the establishment of the outer limits of the continental shelf beyond 200 nautical miles in an area comprising less than 400 nautical miles and subject to the delimitation of the continental shelf between the States concerned cannot be accomplished under the provisions of the Convention. ${ }^{25}$

Japan's position finds support in the Libya/Malta decision. But is there any merit under the law of this protest? The next section addresses this.

\section{Critique of the Libya/Malta Decision}

15. After the decision of the Court in the Libya/Malta case, Colson opined that, "[n]atural prolongation in a physical sense, for all practical purposes was dead". ${ }^{26}$ For Charney, if a Tribunal recognises the doctrine of natural prolongation within 200 nautical miles from the coasts, it would be acting at variance with international law. ${ }^{27}$ Munton records that in a legal opinion co-

23 Japan's Legal Position on the Development of Natural Resources in the East China Sea (Ministry of Foreign Affairs of Japan, 6 August 2015) <www.mofa.go.jp/a_o/c_m1/page3e_000358.html> accessed 12 December 2015.

24 ibid.

25 Japan's Letter to the Secretariat of the UN, Doc SC/09/246 dated 23 July 2009

<www.un.org/Depts/los/clcs_new/submissions_files/preliminary/ipn_re_c hn2009e.pdf $>$ accessed 22 November 2015.

26 D Colson, The Delimitation of the Outer Continental Shelf between Neighboring States, 97 AJIL (2003) 91, 101.

27 Jonathan Charney, 'International Maritime Boundaries for the Continental 
authored by Vaughan Lowe, Christopher Carleton and Christopher Ward assessing the legality of the claim to the continental shelf from the coast of Australia up to the Timor Trough (which dispute is similar to the East China Sea dispute in terms of the positions of the disputing parties- Australia (natural prolongation) and East Timor (distance)- and the length of the area to be delimited being less than 400 nautical miles), it was asserted that in those circumstances, any claim to the continental shelf based on the natural prolongation principle is "inconsistent with international law". ${ }^{28}$ Highet, commenting on the Libya/Malta decision states that " $\mathrm{t}]$ he Libya-Malta case finally disposed of "natural prolongation" once and for all in its most drastic and dramatic form: that of "natural prolongation boundary". ${ }^{29}$ Quite pointedly, Schofield opines that 'States relying on natural prolongationinspired arguments in the context of a maritime boundary determined through binding third-party international judicial dispute resolution should be less than sanguine as to their chances of securing a successful outcome. ${ }^{30}$

16. When one considers these opinions, one may think that the matter is settled and that natural prolongation is actually dead. However, a common thread running through these opinions is that they are not based on an analysis of the decision in light of the law, but on a presumption that the decision of the Court is authoritative, settled and applicable in all cases. This in effect puts a subsidiary means of determining international law above

Shelf: The Relevance of Natural Prolongation' in Nisuke Ando and others (eds), Liber Amicorum Judge Shigeru Oda (Kluwer Law International 2002) 1029.

28 Vaughn Lowe, Christopher Carleton and Christopher Ward (2002) In the Matter of East Timor's Maritime Boundaries: Opinion (unpublished) facts reported in Alexander Munton, A Study of The Offshore Petroleum Negotiations Between Australia, The U.N. and East Timor, (PhD Thesis, Australian National University 2006), 194 <https://digitalcollections.anu.edu.au/handle/1885/47992> accessed 18 February 2016.

29 Keith Highet, Whatever Became of Natural Prolongation, in Dorinda G. Dallmeyer \& Louis DeVorsey (eds.) Rights to Oceanic Resources: Deciding and Drawing Maritime Boundaries, (Martinus Nijhoff Publishers, 1989), 91.

30 Clive Schofield, One Step Forwards, Two Steps Back? Progress and Challenges in the Delimitation of Maritime Boundaries since the Drafting of the United Nations Convention on the Law of the Sea in Guifang Xue and Ashley White (eds.), 30 years of UNCLOS (1982-2012): Progress and Prospects (China University of Political Science Press, 2013), 223. 
primary sources of international law namely, treaties and custom. ${ }^{31}$ Furthermore, it does not give room for the incorporation into subsequent arguments of Article 59 of the ICJ Statute which effectively does away with any idea of stare decisis by providing that the decision of the Court has no binding force except between the parties and in respect of that particular case. This is why Weisburd opines that "[n]othing in the [ICJ] Statute purports to invest in the Court the authority to, in effect, determine the content of international law outside the context of a particular case." 32 Bearing this point in mind, this section assesses the legality of the Libya/Malta decision and its relevance or otherwise to the East China Sea dispute.

\section{IV.A. Two Kinds of Continental Shelves and the 400 Nautical Mile Rule}

17. In the Libya/Malta case, the Court dispensed with the need to consider geological and geophysical factors in determining title within 200 nautical miles of the coasts of disputing States. The Court rightly noted that the law governing continental shelf entitlement had developed to allow States claim up to 200 nautical miles of continental shelf irrespective of the geological or geomorphological characteristics of the seabed. This writer does not dispute this position as same is clear from the wording of Article 76(1) which provides that where a State's continental margin measures less than 200 nautical miles from the coast, then that State may simply claim a 200 nautical mile continental shelf. Nevertheless, the Court assumes incorrectly, that within a given delimitation area, the continental shelf is divided into an inner (within 200 nautical miles of the coast) and an outer (beyond 200 nautical miles of the coast) continental shelf, and within the former, the entitlements of the subject States must be identical. In the inner continental shelf (which in the mind of the Court is primary), the criterion for entitlement is 200 nautical miles while in the outer continental shelf (which the Court assumes to be secondary), geological and geomorphological factors may play a role; and the inner continental shelf must first be apportioned before any consideration of the outer continental shelf may arise. It is this idea that led to the rule that unless the delimitation area is twice the length of the primary, inner continental shelf (that is 400 nautical miles), then a State cannot rely on geological and geomorphological factors (that is the doctrine of natural prolongation to the

31 See Article 38 of Statute of the International Court of Justice.

32 A. Mark Weisburd, The International Court of Justice and the Concept of State Practice, 31 University of Pennsylvania JIL (2009) 295, 371. 
outer edge of the continental margin) for its entitlement to the continental shelf.

18. However, this position is not the law as nowhere in the UNCLOS can the idea of inner and outer continental shelves be found. In the Barbados and Trinidad and Tobago Arbitration Award, the Tribunal noted that 'there is in law only a single "continental shelf" rather than an inner continental shelf and a separate extended or outer continental shelf. ${ }^{33}$ Further, there is just one rule governing delimitation of the continental shelf under Article 83 of the UNCLOS, not one set of rules governing delimitation of an inner continental shelf and another set of rules governing delimitation of an outer continental shelf. ${ }^{34}$ The question becomes: if there is in law only one continental shelf, why then should there be a distinction between the criterion to be used within 200 nautical miles and that to be used beyond that limit? There is no justification for such a practice under the law. Each State's entitlement to the continental shelf ought to be determined on the basis of the fact that it fulfils either of the two criteria for continental shelf entitlement provided for in Article 76(1), namely natural prolongation up to the outer edge of the continental margin or distance where the margin is less than 200 nautical miles. Supporting this view, Legault and Hankey state that

once the existence of a natural prolongation extending beyond 200 miles has been established ... the measurement of that prolongation ... begins at the coast and not at the 200-mile limit. This tends to support the view that there is a single regime of the continental shelf both

3327 RIAA (2006), 147, 208-09, para. 213; Dispute Concerning Delimitation of the Maritime Boundary between Bangladesh and Myanmar in the Bay of Bengal (Bangladesh/Myanmar) Judgment of 14 March 2012. <www.itlos.org/fileadmin/itlos/documents/cases/case_no_16/C16_Judgm ent_14_03_2012_rev.pdf> accessed 6 November 2015, 108, para 362. Compare with Sharma's opinion that a distinction exists between the inner continental shelf and the outer continental shelf. Surya P. Sharma, The Single Maritime Boundary Regime and the Relationship between the Continental Shelf and the Exclusive Economic Zone, 2 International Journal of Estuarine and Coastal Law (1987) 203, 224. Magnússon also argues that entitlement to the inner continental shelf and the outer continental shelf are different. See Bjarni Már Magnússon, The Continental Shelf beyond 200 Nautical Miles: Delineation, Delimitation and Dispute Settlement (Brill Nijhoff, 2015)137.

34 Bangladesh/Myanmar, above n. 33, 108, para 361. 
within and beyond 200 miles.... ${ }^{35}$

\section{IV.B. Independence/Individualisation of Continental Shelf Entitlement}

19. Flowing from the Court's mistaken idea of an identical inner/primary continental shelf, it declared that within 200 nautical miles, no role can be ascribed to geological or geophysical factors when one is in the process of "verifying the legal title of the States concerned or in proceeding to a delimitation as between their claims." 36 This proposition is inconsistent with the law because Article 76(1) does not contemplate equality of the geographical and geological realities of all States or uniformity of entitlement of States in a given delimitation exercise. In fact, the essence of Article 76(1) is the recognition that some States have a naturally wide continental shelf whilst others do not. In view of this, different criteria are provided. On what basis then does the Court make a decision to apply one criterion, namely distance in verifying title of the States concerned?

20. Article 31(1) of the Vienna Convention on the Law of Treaties37 requires that treaties be interpreted in good faith in accordance with the ordinary meaning to be given to the terms of the treaty in their context and in the light of its object and purpose. The word, 'or', employed in Article 76(1) to introduce the additional criterion of distance is defined by the Merriam Webster Dictionary as a word used to denote alternatives. ${ }^{38}$ The dictionary defines "alternative" as "offering or expressing a choice". 39 The Macmillan Dictionary similarly defines "or" as a word used for "connecting possibilities or choices". ${ }^{\circ 0}$ As there is no evidence of a special meaning for the word "or" in Article 76(1), it is clear that both criteria provided therein are alternatives that States can choose from if they satisfy the conditions prescribed. If this is

35 L. H. Legault \& Blair Hankey, From Sea to Seabed: The Single Maritime Boundary in the Gulf of Maine Case, 79 AJIL (1985) 961, 983.

36 Italics added. Libya/Malta case, above n.1, 35, para 39.

$37 \quad 1155$ UNTS 331

38 'Or|Definition of or' (Merriam-Webster) <http://www.merriamwebster.com/dictionary/or> accessed 16 October 2015.

39 'Alternative|Definition of Alternative' (Merriam-Webster) <http://www.merriam-webster.com/dictionary/alternative> accessed 16 October 2015.

40 'Or Definition and Synonyms' (Macmillan Dictionary) <http://www.macmillandictionary.com/dictionary/british/or> accessed 16 October 2015. 
not the case, one is inclined to ask what the value of having alternatives is, if one cannot choose.

21. The Virginia Commentary recognises the existence of alternatives in Article 76(1) when it states that "a coastal state may apply either a geomorphologic criterion or a distance criterion in determining the outer limit of its continental shelf." 41 Note the individualisation of a State's entitlement and the recognition of the existence of alternatives in the use of the words "either or". Note also the departure from the blanket grouping under one criterion, namely distance, as promoted in the Libya/Malta decision. Serdy holds a similar view. He shows that reference to the term "baselines" throughout the UNCLOS is reference to the baselines of a single coastal State not to the baselines of all neighbouring States of a particular sea area. ${ }^{42}$ Specifically, Article 76(1) provides that "[t]he continental shelf of a coastal State comprises the seabed and subsoil ... that extend beyond its territorial sea throughout the natural prolongation of its land territory to the outer edge of the continental margin." 43 Note again the singularisation of a coastal State's entitlement with the use of the words "a coastal State", and the use of the possessive adjectives "its territorial sea" and "its land territory" in the article to specify what entitlement entails. 44 This writer contends that to interpret otherwise is to defeat the object and purpose of Article 76(1), namely the provision of different criteria for asserting entitlement to the continental shelf.

22. It is interesting to note that the entire area subject to delimitation in the Libya/Malta case was less than 200 nautical miles. The maximum distance was 183 nautical miles.45 If the Court had based its decision to reject geological and geophysical characteristics of the seabed in favour of distance as contained in Article 76(1) on this fact that the whole area was less than 200 nautical miles, it would have made a decision within the bounds of the law.

41 Italics added. Myron H Nordquist, Satya Nandan and Shabtai Rosenne (eds.), 2 United Nations Convention on the Law of the Sea, 1982: A Commentary, (Martinus Nijhoff Publishers, 1993), 841

42 Andrew Serdy, Is there a 400-Mile Rule in UNCLOS Article 76(8)?, 57 ICLQ (2008) 941, 948-50.

43 Italics added.

44 Serdy, above n.42, 949-50.

45 Libya/Malta case, above n.1, 20-21, para 16; Seokwoo Lee and Young Park, Maritime Delimitation and Joint Resource Development in the East China Sea in Law of the Sea Institute Conference Papers: Securing the Ocean for the Next Generation (2012) 15. 
This is because Article 76(1) clearly states that where the continental margin of a State does not extend up to 200 nautical miles, then entitlement is based on a distance of 200 nautical miles measured from the coast. Therefore if the whole area subject to delimitation is less than 200 nautical miles, how could either of the disputing States rely on a criterion other than that of 200 nautical mile distance? Certainly, neither of them could fulfill the criterion of natural prolongation extending beyond 200 nautical miles up to the outer edge of the continental margin. But the geographical realities in the East China Sea are different. In the former, the area to be delimited is greater than 200 nautical miles and the outer edge of the continental margin is located more than 200 nautical miles from the coasts of one of the States, China.

23. Again, observe that the Court stated that "it follows that, since the distance between the coasts of the Parties is less than 400 miles ...[,] no geophysical feature can lie more than 200 miles from each coast". ${ }^{46}$ This statement would have been correct if (a) it was limited to the specific facts between Libya and Malta since the whole area measured just 183 nautical miles, there being no reason to speak about geophysical features lying beyond 200 nautical miles, and (b) if the Court had substituted the number 200 for 400. Outside of these specific facts between Libya and Malta, the reality is that geophysical features can lie more than 200 nautical miles from the coasts of neighbouring States even if the entire area is less than 400 nautical miles as depicted in the East China Sea. ${ }^{47}$ The Okinawa Trough lies more than 200 nautical miles from China but within 200 nautical miles from Japan. These important differences in facts make the Libya/Malta decision an incorrect precedent for the resolution of the East China Sea dispute.

24. By refusing to recognise the doctrine of natural prolongation when the delimitation area is less than 400 nautical miles, the Court has created the problem, namely that the entitlement a State has to the continental shelf is dependent on the entitlement a neighbouring State has to the continental shelf. Put differently, when State A claims entitlement to the continental shelf based on the distance criterion, State B cannot assert entitlement on any other basis, but must also follow the distance criterion insofar as the delimitation area measures less than twice State A's distance-based entitlement. This certainly cannot be the case, for every State is entitled to the continental shelf independently of another State. The right to the continental shelf is a standalone right, and the entitlement of a neighbouring coastal State is

46 ibid., 35, para 39

47 This is also the case in the Timor Sea. See Serdy, above n. 42, 941. 
immaterial to the entitlement of another. It would be absurd to conceive of a State's entitlement to the continental shelf as being dependent on the title a neighbouring State has to the continental shelf. Where then would one place the very fundamental notion of inherent entitlement to the continental shelf enshrined in Article 77(3) of the UNCLOS and how does one determine which State's entitlement is dependent on the other's? A consideration of the presence of another State and the maritime space it may be entitled to would only arise during delimitation; and the issue of delimitation only arises after a determination of entitlement. Thus, continental shelf entitlement must be understood in relation to each individual State.

25. Considering the question of inherent right to the continental shelf extending beyond 200 nautical miles, Ribeiro opines that this inherency operates whether the continental shelf ends at 200 nautical miles or beyond. She states that

It is surely not correct to adopt a restrictive interpretation of LOSC Article 77(3) and apply it only up to the $200 \mathrm{~nm}$ limit. Such an understanding would restrict the scope of the Article.... Such an interpretation is not supported by Article 77(3) itself, because it makes no distinction, when compared with what is set out in LOSC Article 76(1), between the situations in which the continental shelf reaches the limit of $200 \mathrm{~nm}$, and the situations in which the continental shelf goes beyond that limit. Such a distinction would not make sense. ${ }^{48}$

26. Applying this argument to the East China Sea dispute, the fact that Japan relies on the distance criterion should not in any way preclude China from asserting its rights based on the natural prolongation criterion. Each party's entitlement is independent of the other's and should command validity. Therefore, when the Court in the Libya/Malta case stated that as far as areas situated at a distance under 200 nautical miles are concerned, title depends solely on distance, 49 this could only be true in relation to State A whose continental margin does not extend up to 200 nautical miles. It could not be true for State B whose margin extends beyond 200 nautical miles because State B's entitlement is not in any way dependent upon the entitlement State

48 Marta Chantal Ribeiro, The "Rainbow": The First National Marine Protected Area Proposed Under the High Seas, 25, International Journal of Marine and Coastal Law (2010) 183, 191.

49 Libya/Malta case, above n.1, 35, para 39. 
A has to the continental shelf. Indeed, it would be inequitable to decide that State B must refrain from exercising its rights under the Convention that entitles it to a wider maritime area just because State A cannot, in any way, assert a right to anything more than 200 nautical miles. Again, when the Court held that geophysical and geological characteristics are immaterial since a State may on the basis of the Convention claim a continental shelf extending up to 200 nautical miles, ${ }^{50}$ this must be understood as appertaining to the State whose continental margin does not extend beyond 200 nautical miles, necessitating it to settle for 200 nautical miles as its allowed maximum. It would be inequitable to require wide margin States which have a right to plead the natural prolongation part of Article 76 to disregard the geological and geophysical characteristics of the sea bed and subsoil, when that is in essence the basis of their entitlement to the continental shelf beyond 200 nautical miles.

27. In this regard, writing within the context of establishing a continental shelf extending beyond 200 nautical miles in an area less than 400 nautical miles, Serdy states that

if recourse to the travaux is had under Article 32 of the Vienna Convention because the Article 31 approach leaves the meaning ambiguous or obscure, it would have been no less reasonable an intent of the drafters - and no less consistent with the available evidence in this regard - to require a coastal State to justify on geomorphological or geological grounds any extension of its continental shelf beyond 200 miles from its own baselines, irrespective of whether any other nearby State could have exercised sovereign rights over the area on the distance criterion. ${ }^{51}$

\section{IV.C. Libya/Malta Decision on the Relationship between the EEZ and the Continental Shelf}

28. Finding additional justification for its elevation of the distance criterion, the Court in the Libya/Malta case referred to the 200 nautical mile EEZ provided for in Article 57 of the UNCLOS as a relevant factor in delimiting the continental shelf, quite apart from the 200 nautical mile continental shelf provided for in Article 76(1). In view of this, the Court stated that, "greater

50 ibid

51 Serdy, above n.42 at 400. 
importance must be attributed to elements, such as distance from the coast, which are common to both concepts." 52 It based this decision on the fact that there can be a continental shelf without an EEZ but there cannot be an EEZ without a continental shelf. ${ }^{53}$ Assuming that the Court's assertion is true that there can be a continental shelf without an EEZ but there cannot be an EEZ without a continental shelf, would it not follow that it is in the delimitation of the EEZ that one is to take into consideration factors relevant to the continental shelf and not the other way round? This is because if there can be a continental shelf without an EEZ, therefore EEZ considerations are not automatically vital to the delimitation of the continental shelf. Moreover, the right to the continental shelf is inherent whereas the right to the EEZ is not. ${ }^{54}$

29. Supporting this line of argument is the requirement by Article 56(3) that the rights over the seabed of the EEZ be exercised "in accordance with" the rights over the continental shelf. Thus Article 56(3) makes the seabed rights of the EEZ subject to the seabed rights of the continental shelf. The Free dictionary defines "in accordance with" to mean "in conformity to" or "in agreement with". ${ }^{5}$ "This means that the reference point is the continental shelf regime to which the EEZ seabed regime must conform. O'Connell argues that the UNCLOS is proof of the fact that the doctrine of the continental shelf is not one that is to be committed to oblivion insofar as it refers the rights to be exercised in relation to the seabed and subsoil of the EEZ to the rights exercisable over the continental shelf. 56 Similarly, Miyoshi notes that concerning the seabed of the EEZ, the regime of the continental Shelf takes precedence by virtue of Article 56(3).57 Thus it is in the delimitation of the EEZ that factors pertinent to the continental shelf may be

$52 \quad$ Libya/Malta case, above n.1, 33, para 33.

53 ibid 33, para 44.

54 Art 77(3) UNCLOS; Ted L McDorman, Rights and Jurisdiction over resources in the South China Sea: UNCLOS and the "nine-dash line," in S. Jayakumar, Tommy T. B. Koh, and Robert C. Beckman (eds.), The South China Sea disputes and Law of the Sea (Edward Elgar, 2014), 159.

55 "In Accordance with" (The Free Dictionary) $<$ http://idioms.thefreedictionary.com/in+accordance+with $>$ accessed 2 December 2015.

56 DP O'Connell, 2 The International Law of the Sea, (IA Shearer ed, Clarendon Press 1982) 730.

57 Masahiro Miyoshi, The Joint Development of Offshore Oil and Gas in Relation to Maritime Boundary Delimitation, in: Clive Schofield (ed.), 5 Maritime Briefing (IBRU, 1999), 44. 
considered and not the other way round. If the factors necessary for determining entitlement are the factors pertinent for its delimitation, why did the Court decide that it must find the factors necessary for entitlement to the EEZ as pertinent for the delimitation of the continental shelf, especially where the parties to the dispute had not required it to delimit an EEZ at all?

30. Further analysis shows that the Court's position on the relationship between the continental shelf and the EEZ is tantamount to the Court declaring, in essence, that whenever it is called upon to delimit the continental shelf, it would also delimit the EEZ. ${ }^{8}$ Put differently, it would always delimit a single maritime boundary since it relies for its delimitation on factors common to both zones, namely 200 nautical mile distance from the coast. If 200 nautical miles distance from the coast is the basis of a delimitation exercise of the continental shelf and the EEZ, it follows that what has been delimited is the EEZ or a single maritime boundary. This idea is not farfetched when one considers that the single maritime boundary is regarded as an EEZ boundary. The Report of the International Committee on the Exclusive Economic Zone submitted to the International Law Association at its 1986 Seoul conference states that the single maritime boundary "is indeed simply the boundary of the exclusive economic zone".59 Again, Tanaka notes that where an EEZ is declared, the seabed is no longer that of the continental shelf but the seabed of the EEZ. Accordingly, the single maritime boundary is the EEZ boundary. ${ }^{60}$ Sharma records that in the Case Concerning Delimitation of the Maritime Boundary in the Gulf of Maine Area (Canada/United States of America), 61 both the Unites States and Canada appeared to treat the single maritime boundary as the boundary of the EEZ, a position which the Court also seemed to take. ${ }^{62}$ Legault and Hankey also opine that neither the United States, Canada nor the Chamber in the Gulf of Maine case seemed to have

58 Prescott opines that '[i]t is almost as though countries sharing seas less than $400 \mathrm{~nm}$ wide would be drawing EEZ boundaries rather than continental shelf boundaries'. J. R Prescott, Maritime Jurisdiction in East Asia Seas (EastWest Environment and Policy Institute, 1987) 38.

59 The Relationship between the Exclusive Economic Zone and the Continental Shelf in the International Law Association Report of the SixtySecond Conference Held at Seoul (August 24-30, 1986) (International Law Association, 1987) 12, para 41.

60 Yoshifumi Tanaka, Predictability and Flexibility in the Law of Maritime Delimitation (Hart Publishing 2006) 16, footnote 63.

61 ICJ Reports 1984, 246 (Gulf of Maine)

62 Sharma, above n. 33 at 204. 
taken there to be any material difference between the law governing delimitation of the continental shelf and the EEZ by means of a single maritime boundary and the law governing the delimitation of the EEZ. They further add that there seemed to be a presumption on the part of the Chamber that the single maritime boundary concerned the EEZ more. ${ }^{63}$

31. In the Libya/Malta case, the Court's decision to apply elements, namely distance, common to both the regimes of the EEZ and the continental shelf to the delimitation of only the continental shelf bears a striking similarity with the Chamber's decision in the Gulf of Maine case. In the latter case, the Chamber decided to apply only "neutral" factors (that is factors not preferential to one zone to the detriment of the other) for the drawing of a single maritime boundary for both the EEZ and the continental shelf. So in the one case, the Court decides that it will rely on factors common to the regime of the EEZ and the continental shelf for the delimitation of only the continental shelf, whilst in the second case, the Chamber applies the same factors (though in this instance referred to as "neutral" factors) to the delimitation of both the continental shelf and the EEZ. A close examination of the words "neutral" and "common" in the contexts used in the two cases under reference show that there is no material difference between them. Neutral criteria in the Gulf of Maine case meant criteria common to both the EEZ and the continental shelf; criteria unaligned, unbiased, not favouring one to the detriment of the other; criteria equally suited to the division of the continental shelf and the EEZ, ${ }^{64}$ thus excluding as irrelevant for the then present purposes, criteria such as the geological character of the seabed because it gave preference to continental shelf delimitation to the detriment of the EEZ. 65 Similarly, in the Libya/Malta case, "common elements" refer to 200 nautical miles distance from the coast; a criterion that is shared by both the EEZ and the continental shelf, seemingly unaligned to either of them, and that excludes geological and geomorphological factors for the same reasons as in the Gulf of Maine case, namely a preference in favour of the continental shelf to the detriment of the EEZ. In fact, Churchill refers to the factors chosen for the delimitation of the single maritime boundary by the Chamber in the Gulf of Maine case as factors "common" to the continental shelf and the EEZ. ${ }^{66}$ Also,

63 Legault and Hankey, above n. 35 at 976-77.

64 Gulf of Maine case, above n. 61, 327 para 194.

65 ibid., 327, para 193.

66 R.R. Churchill, The Greenland-Jan Mayen Case and its Significance for the International Law of Maritime Boundary Delimitation, 9 International 
Judge Shahabuddeen, in his separate opinion in the Maritime Delimitation in the Area between Greenland and Jan Mayen (Denmark v. Norway) ${ }^{67}$ stated that the only way to arrive at a single maritime boundary 68 is to embark on a process of selection where the Court chooses only those factors that are "common" to the EEZ and the continental shelf. 69

32. The above analysis shows that the Court in the Libya/Malta case created a new rule whereby States have to delimit a single maritime boundary whenever the delimitation of the continental shelf is in issue, in areas less than 400 nautical miles. The Court was implying that it would always delimit a single maritime boundary (or an EEZ boundary) whenever it is called upon by States to delimit their continental shelves since it would apply factors common to the delimitation of the EEZ and the continental shelf.70 Nevertheless, Judge Shahabuddeen warned that applying factors common to the delimitation of both zones "could involve the non-use of some criteria the use of which would otherwise have been required by international law were the Court engaged in delimiting one space only." 71 Incidentally, that is an exact reflection of the Court's reasoning in the Libya/Malta case because it excludes the criterion of natural prolongation which international law requires to be taken into consideration in the delimitation of the continental shelf in certain instances, namely where the continental margin of a State extends beyond 200 nautical miles. At any rate, the Court was dealing only with the delimitation of the continental shelf, yet its preoccupation with the EEZ (or a single maritime boundary) ${ }^{72}$ led it to advocate for a disregard of natural

Journal of Marine and Coastal Law (1994) 1, 22.

67 ICJ Reports 1993, 38 (Jan Mayen case)

68 In this instance, Judge Shahabuddeen was particularly referring to drawing two lines that are co-incident but the substance of his argument shows that in reality, he is setting out the reasoning behind drawing what is referred to as single maritime boundary lines because he goes on to argue that this process of selectively choosing only factors common to the different zones to be delimited would exclude the factors required under international law to be taken assuming the Court was engaged in the delimitation of one zone only.

69 Jan Mayen case, above n.67, (sep. op. Shahabudeen) 199.

70 Sharma opines that the preferential position given to distance and the integration of the EEZ and the continental shelf raises an initial legal presumption in favour of single maritime boundaries. Sharma, above n.33, 226.

71 ibid.

72 McDorman opines that the Court carried out the delimitation as if it was 
prolongation or geological and geophysical factors which are the factors necessary to be established in the case of a continental shelf extending beyond 200 nautical miles. This disregard, in turn, has the effect of depriving States of continental shelf areas to which they may be entitled.

33. When this effect is contrasted with the fact that at UNCLOS III, States with a continental shelf extending beyond 200 nautical miles rejected the absorption of the continental shelf regime into the EEZ regime, one cannot help but notice that the reasoning of the Court in the Libya/Malta case is a judicial creation, that places limitations on the sovereignty of coastal States and takes away their right to determine the rules by which they would be bound in their relations on the international sphere as far as it concerns the uses of the sea. Legault and Hankey rightly note that

The reasons for the maintenance of these separate parts are well known. They have to do with the determination of the wide-margin states, those having a physical continental shelf extending beyond 200 miles from the coast, not to surrender the rights they possessed in respect of the outer continental shelf under the 1958 Continental Shelf Convention and customary international law. These rights might have lapsed if the preexisting regime of the continental shelf had been extinguished and replaced solely by the new regime of the exclusive economic zone. The purpose of maintaining the two parallel parts of the 1982 Convention was therefore to protect the rights of the widemargin states to jurisdiction over the continental shelf beyond the 200mile limit.73

34. If the main purpose of retaining separate regimes for the continental shelf and the EEZ in the UNCLOS is to protect the rights of wide-margin States, ensuring that their rights to the continental shelf is not limited to 200 nautical miles, then the Libya/Malta decision should be regarded as contrary to the express agreement of the State parties to the UNCLOS. As Antunes notes, maritime entitlement derive from rules that legally empower States to exercise certain rights over the maritime area; 74 and if one may ask where these rules

delimiting a single maritime boundary. Ted L McDorman, The Libya-Malta Case: Opposite States Confront the Court, 24 Canada YBIL (1986) 335, 360.

73 Legault and Hankey, above n. 35 at 981.

74 Nuno Antunes, Towards the Conceptualisation of Maritime Delimitation: Legal and Technical Aspects of a Political Process, (Durham University 2002) 
came from, the answer would always be that they are rules created by States in the form of treaties or through custom. They are not rules derived from judicial creations which is what the Court in the Libya/Malta case has done; the question at all times material must be: what rules did the States create?

35. Accordingly, a single maritime boundary cannot be made obligatory where one of the disputing States concerned has indicated that it does not wish for a single boundary for the delimitation of overlapping zones. That is why Judge Oda, in the Jan Mayen case disagreed with Denmark's assumption that a single maritime boundary be drawn, as this position stemmed from Denmark's apparent disregard of the separate regimes of the continental shelf and the EEZ. Judge Oda therefore opined that "[i]n the absence of an agreement between the States concerned, one cannot presuppose a single delimitation for two separate and independent régimes, the exclusive economic zone and the continental shelf...."75 $\mathrm{He}$ further added that in view of this separateness, the delimitation for each of these zones is different. ${ }^{76}$ Similarly, Churchill states that in the absence of agreement between the States concerned, the Court cannot legally, under the guise of classifying factors as "common" to two different zones, exclude factors required by law to be taken into consideration in the delimitation of a particular zone. 77

36. Applying this analysis to the East China Sea dispute, it is argued that a single maritime boundary will not suffice for resolving the dispute except both States agree to it. As single maritime boundaries find expression in the will of States, not being a product of the UNCLOS or any other multilateral treaty ${ }^{78}$ it is not possible to compel a State to accept a single line. In the absence of agreement for a single line therefore, the solution lies in drawing separate lines for the continental shelf and the EEZ; specifically, separate lines for the seabed and subsoil and for the water column. Insofar as the drawing of a single line will give preferential treatment to the criterion of distance to the detriment of natural prolongation, which is a very important

$137<$ http://etheses.dur.ac.uk/4186/> accessed 20 January 2015.

75 Jan Mayen case, above n.67 (sep. op. Oda) 109, para 70; Malcolm D. Evans, Case Concerning Maritime Delimitation in the Area between Greenland and Jan Mayen, 43 ICLQ (1994) 697, 702.

76 Jan Mayen case, above n.67 (sep. op. Oda) 110, para 73.

77 Churchill, above n.66, 11.

78 Maritime Delimitation and Territorial Questions between Qatar and Bahrain (Qatar v. Bahrain) ICJ Reports 2001, 40, 93, para 173. 
aspect of the East China Sea dispute, ${ }^{79}$ it is unsuitable for resolving the dispute. Here again, the reasoning in the Libya/Malta case is shown to be inapplicable.

37. The drawing of different lines for the continental shelf and the EEZ, though not common, has been used where it was necessary to take into account the peculiar circumstances of the area to be delimited. Churchill and Lowe note that what is equitable for the EEZ may be inequitable for the continental shelf because of the different relevant circumstances necessary to be considered in order to achieve an equitable solution for each zone. ${ }^{80}$ Tanaka also opines that different outcomes may result from the application of the identical rules of EEZ and continental shelf delimitation because the relevant circumstances considered for the delimitation of both zones are different. ${ }^{81}$ In the Australia-Papua New Guinea Maritime Boundaries Treaty of $1978,{ }^{82}$ the line delimiting the fisheries zone differed from the line delimiting the seabed in the Torres Strait; this line was adopted in order to recognise the important place of fishing to the inhabitants of some Australian islands located close to Papua New Guinea. ${ }^{33}$ Also, in the Australia-Indonesia Maritime Boundaries Treaty of 1997,84 separate lines are used to delimit the continental shelf and the EEZ. Article 7 of that Treaty provides that:

In those areas where the areas of exclusive economic zone adjacent to and appertaining to a Party (the First Party) overlap the areas of seabed adjacent to and appertaining to a Party being the other Party (the

79 Gulf of Maine case, above n.55, 327, para 194.

80 RR Churchill and AV Lowe, 3 The Law of the Sea (Manchester University Press 1999) 196.

81 Tanaka, above n.60, 15.

82 Treaty between Australia and the Independent State of Papua New Guinea concerning sovereignty and maritime boundaries in the area between the two countries, including the area known as Torres Strait, and related matters, 18 December 1978 <www.un.org/Depts/los/LEGISLATIONANDTREATIES/PDFFILES/T REATIES/AUS-PNG1978TS.PDF> accessed 2 December 2015.

83 Tanaka, above n.60, 338.

84 Treaty between the Government of Australia and the Government of the Republic of Indonesia establishing an exclusive economic zone boundary and $\begin{array}{lllll}\text { certain seabed } & \text { boundaries, } & 14 & \text { March } & 1997\end{array}$ <http://www.un.org/depts/los/LEGISLATIONANDTREATIES/PDFFILES /TREATIES/AUS-IDN1997EEZ.pdf> accessed 20 October 2016. 
Second Party): (a) the First Party may exercise exclusive economic zone sovereign rights and jurisdiction provided for in the 1982 Convention in relation to the water column; (b) the Second Party may exercise continental shelf sovereign rights and jurisdiction provided for in the 1982 Convention in relation to the seabed;

38. That same Article also provides for co-operation between Parties in the exercise of their respective rights and jurisdictions, with each party to refrain in the exercise of its rights and jurisdiction from acts that unduly inhibit the other Party's exercise of its rights and jurisdiction.

39. It is interesting to note that both of these cases involved Australia, a State that is currently the only other State apart from China that claims an entitlement to the continental shelf extending throughout the natural prolongation of its land territory beyond 200 nautical miles and up to the outer edge of the continental margin in a space measuring less than 400 nautical miles in the Timor Sea. This provides evidence of relevant State practice that separate boundary lines for the continental shelf and the EEZ should be adopted where (a) the aim is to achieve an equitable solution (b) a single line will not lead to the achievement of that equitable solution and (c) both parties are not in agreement that a single line be drawn.

While it is conceded that the Australian-Indonesian agreement has never been ratified and has in fact being superseded by the independence of East Timor which now seeks a different solution from the one adopted under the agreement, it does not take away the fact that the line of solution suggested in this article has previously been considered and adopted by States having a significant interest in the subject matter. While East Timor and Australia are currently undergoing compulsory conciliation ${ }^{85}$ under Section 2, Annex V of the UNCLOS in relation to the determination of their maritime boundaries, which conciliation is being conducted in confidential settings, ${ }^{86}$ it is not apparent that Australia has changed its long-held position that natural prolongation is a valid basis for continental shelf entitlement in the Timor Sea

85 The report of the conciliation commission is not binding. Article 7, Section 2, Annex V of UNCLOS.

86 Permanent Court of Arbitration, 'Press Release: Conciliation between the Democratic Republic of Timor-Leste and the Commonwealth of Australia Press' 2 (26 September 2016) <https://pca-cpa.org/wpcontent/uploads/sites/175/2016/09/Press-Release-No.-4-EN.pdf $>$ accessed 20 November 2016. 
and consequently, that different lines may be used to delimit the continental shelf and the EEZ.

\section{Equitable Solution in the East China Sea?}

40. In view of the inapplicability of the Libya/Malta decision to the East China Sea dispute as shown above, what then would constitute an equitable solution? It is submitted that an equitable solution would be one which allows the coasts of the parties generate their entitlements in a reasonable and mutually balanced way. ${ }^{87}$ This is also expressed as the equitable principle that the coastal State should be allowed to "enjoy sovereign rights over the continental shelf off its coasts to the full extent authorized by international law in the relevant circumstances". ${ }^{88}$ In the East China Sea, this would mean recognising the entitlements of both China and Japan on the basis of natural prolongation and distance respectively, and then proceeding to a delimitation of the overlapping area created by this recognition. ${ }^{89}$ This solution satisfies the equitable principle that the inequalities of nature be not compensated for but that all States be treated equally before the law. ${ }^{90}$

\section{Conclusion}

41. In the East China Sea dispute, China and Japan disagree on the basis of title to the continental shelf. While China relies on natural prolongation and seeks to establish the outer edge of the continental margin beyond 200 nautical miles from its coast, Japan contends that the distance principle is applicable and relies on the Libya/Malta decision for its position. This article revisited the Libya/Malta case, critiquing the important parts of the judgment that some scholars have assumed constitute 'gospel truths' in the law of maritime boundary delimitation. Through an analysis of the decision, this article has shown that the case is an incorrect precedent for the resolution of the East China Sea dispute.

87 Territorial and Maritime Dispute (Nicaragua v. Colombia) ICJ Reports 2012, 624, 703, para 215; Maritime Delimitation in the Black Sea (Romania v. Ukraine) ICJ Reports 2009, 61, 127, para. 201.

88 Libya/Malta case, above n.1, 39, para 46.

89 GAO Jianjun, Joint Development in the East China Sea: Not an Easier Challenge than Delimitation, 23 The International Journal of Marine and Coastal Law (2008) 39, 45.

$90 \quad$ Libya/Malta case, above n.1, 39, para 46. 
42. The decision is hinged on the wrongful notion that there is an inner and an outer continental shelf, with the former being primary and the latter secondary; that within the primary inner continental shelf, the 200 nautical mile distance criterion is applicable and unless the delimitation area measures at least 400 nautical miles, there is no role for geological and geomorphological factors in determining title and consequently, delimitation. This position has been shown to be in contradiction to the doctrine of a single continental shelf. Moreover, the facts presented in the East China Sea dispute-particularly, the presence of a continental margin beyond 200 nautical miles of one of the States as opposed to a rift zone situated within 200 nautical miles of the coast of the claiming State-differ from those in the Libya/Malta case, warranting a different conclusion from the one reached in that case. In the Libya/Malta case, the delimitation area measured just 183 nautical miles and only the distance criterion could be asserted by the disputing States in light of Article 76(1) of the UNCLOS.

43. Relying on the fundamental notion of an inherent right to the continental shelf, this article questioned the Court's reasoning that contemplates equality of maritime entitlements within a certain breath and then divergence after that limit. Arguing that Article 76(1) provides alternative criteria for continental shelf entitlement and each State's entitlement is independent of the other, this article emphasised the individualisation of each State's entitlement in the UNCLOS to prove that China should not be precluded from relying on the natural prolongation principle as suggested in the Libya/Malta decision.

44. Concerning the Court's treatment of the EEZ as a relevant factor in continental shelf delimitation, this article showed that EEZ considerations are not automatically relevant in continental shelf delimitation because there can be a continental shelf without an EEZ. The Court's decision to apply factors common to both the EEZ and the continental shelf in the delimitation of only the continental shelf is equivalent to delimiting a single maritime boundary. As single maritime boundaries require the exclusion of criteria that would otherwise have been applicable if the zones were delimited separately and in view of the fact that what is equitable for one zone may be inequitable for another zone, ${ }^{91}$ then in the absence of agreement between the disputing States, a single maritime boundary cannot be drawn. In the East China Sea, there is no agreement on a single maritime boundary; the equitable solution therefore lies in the drawing of separate boundaries for the different zones,

91 Churchill and Lowe, above n. 80, 196. 
with the delimitation of each zone taking cognisance of circumstances relevant thereto.

45. In the continental shelf delimitation, geological and geomorphological factors would constitute relevant circumstances, notwithstanding that the area to be delimited is less than 400 nautical miles for the reasons advanced herein. A simultaneous recognition of the entitlements of both China and Japan on the basis of natural prolongation and distance respectively will ensure that each party is allowed to enjoy its entitlement as provided for under international law. 